WSRC-MS-2003-00595, Revision 0

\title{
CHARACTERIZATION AND PERFORMANCE OF FLUIDIZED BED STEAM REFORMING (FBSR) PRODUCT AS A FINAL WASTE FORM
} (U)

C.M. Jantzen

Westinghouse Savannah River Company

Aiken, SC 29808

A paper for publication in the Symposium on Waste Management Technologies in Ceramic and Nuclear Industries, American Ceramic Society, Westerville, Ohio. 
This document was prepared in conjunction with work accomplished under Contract No. DE-AC09-96SR18500 with the U. S. Department of Energy.

\section{DISCLAIMER}

This report was prepared as an account of work sponsored by an agency of the United States Government. Neither the United States Government nor any agency thereof, nor any of their employees, makes any warranty, express or implied, or assumes any legal liability or responsibility for the accuracy, completeness, or usefulness of any information, apparatus, product or process disclosed, or represents that its use would not infringe privately owned rights. Reference herein to any specific commercial product, process or service by trade name, trademark, manufacturer, or otherwise does not necessarily constitute or imply its endorsement, recommendation, or favoring by the United States Government or any agency thereof. The views and opinions of authors expressed herein do not necessarily state or reflect those of the United States Government or any agency thereof.

This report has been reproduced directly from the best available copy.

Available for sale to the public, in paper, from: U.S. Department of Commerce, National Technical Information Service, 5285 Port Royal Road, Springfield, VA 22161, phone: (800) 553-6847, fax: (703) 605-6900

email: orders@ntis.fedworld.gov

online ordering: http://www.ntis.gov/help/index.asp

Available electronically at http://www.osti.gov/bridge

Available for a processing fee to U.S. Department of Energy and its contractors, in paper, from: U.S. Department of Energy, Office of Scientific and Technical Information, P.O. Box 62, Oak Ridge, TN 37831-0062,

phone: (865)576-8401,

fax: (865)576-5728

email: $\underline{\text { reports@ adonis.osti.gov }}$ 


\title{
CHARACTERIZATION AND PERFORMANCE OF FLUIDIZED BED STEAM REFORMING (FBSR) PRODUCT AS A FINAL WASTE FORM
}

\author{
C.M. Jantzen \\ Savannah River Technology Center \\ Westinghouse Savannah River Co. \\ Aiken, SC 29808
}

\begin{abstract}
A demonstration of Fluidized Bed Steam Reforming (FBSR) was recently completed on a Hanford Low Activity Waste (LAW) simulant. This technology produced stable mineral phases (feldspathoids) when co-fired with clay. The mineral phases are cage structured and were determined to retain anions such as $\mathrm{SO}_{4}{ }^{=}$as well as cations such as $\mathrm{Re}$ (simulant for Tc) in the mineral cages. The mineral phases are produced at moderate steam reformer operating temperatures between $650-750^{\circ} \mathrm{C}$. The FBSR mineral waste form exhibited incongruent leaching characteristics during Product Consistency Testing (PCT or ASTM $\mathrm{C} 1285$ ). The radionuclides ( $\mathrm{Cs}$ and $\mathrm{Re}$ as simulants for $\mathrm{Cs}^{137}$ and $\mathrm{Tc}^{99}$ ) are released in significantly lower concentrations than $\mathrm{Na}$. In addition, the $\mathrm{Na}$ release is less than the $2 \mathrm{~g} / \mathrm{m}^{2}$ Hanford contract requirement for vitrified LAW. FBSR mineral waste forms are EPA regulatory compliant at the Universal Treatment Standard (UTS) making delisting an attractive option for this waste form.
\end{abstract}

\section{INTRODUCTION}

The Hanford LAW is a basic high $\mathrm{Na}^{+}$molarity $(\sim 8.1 \mathrm{M})$ sodium nitrate sodium hydroxide solution that also contains significant amounts of sulfate, chloride, fluoride and organic compounds as well as certain heavy metals and radionuclides. LAW is the low activity salt supernate fraction of Hanford High Level Liquid Waste (HLLW). In December 2001, Fluiduized Bed Steam Reforming (FBSR), was investigated for stabilization of LAW waste by THOR Treatment Technologies (TTT) using the patented THermal Organic Reduction $\left(\mathrm{THOR}^{\mathrm{sm}}\right.$ ) process. This process, developed by Studsvik, utilizes 
pyrolysis*/steam reforming to destroy both organics and nitrates/nitrites in the waste. The FBSR demonstrations were performed on $\sim 150$ gallons of a Hanford AN-107 LAW simulant simultaneously being used for a vitrification demonstration. The radionuclide $\mathrm{Tc}^{99}$ was simulated with $\mathrm{Re}$ while $\mathrm{Cs}^{137}$ was simulated with stable cesium $\left(\mathrm{Cs}^{133}\right)$.

The non-radioactive AN-107 simulant of $8.1 \mathrm{M} \mathrm{Na}^{+}$was successfully tested in a 6-inch TTT pilot scale facility. ${ }^{\dagger}$ Other demonstrations performed by TTT showed that LAW waste could be transformed into $\mathrm{Na}_{2} \mathrm{CO}_{3}, \mathrm{NaAlO}_{2}$, or $\mathrm{Na}_{2} \mathrm{SiO}_{3}$ feed material for the LAW Hanford melter (Table I). Addition of no solid coreactant yielded a sodium carbonate product. Sodium will combine with carbon dioxide in the reformer gases to provide a sodium carbonate product. The generation of sodium carbonate in this type of application has been known since the 1950s in fluid bed denitration systems [1]. Addition of an $\mathrm{Al}(\mathrm{OH})_{3}$ coreactant will provide an $\mathrm{NaAlO}_{2}$ product, addition of $\mathrm{SiO}_{2}$ will provide an $\mathrm{Na}_{2} \mathrm{SiO}_{3}$ product, while addition of clay will provide a final mineral waste form product (Table I). The latter has been shown to perform well as a final waste form $[2,3]$. Testing on Hanford LAW surrogates has shown that over $95 \%$ of the sulfur compounds, fluorides and chlorides in the waste feed react in the steam reformer with the clay co-reactant and become an integral part of the final mineral waste product structure [2].

Table I. THOR ${ }^{\text {sm }}$ Pilot Scale Demonstrations with Simulated LAW Wastes

\begin{tabular}{|c|c|c|c|}
\hline $\begin{array}{c}\text { \# Pilot } \\
\text { Runs }\end{array}$ & $\begin{array}{c}\text { Solid } \\
\text { Additive }\end{array}$ & Mineral Product & Purpose \\
\hline 5 & Clay & $\begin{array}{l}\text { Feldspathoid minerals } \\
\text { (nepheline and sodalite) that } \\
\text { stabilize problematic anions } \\
\text { such as } \mathrm{Cl}, \mathrm{F} \text {, and } \mathrm{SO}_{4}\end{array}$ & $\begin{array}{l}\text { Stabilization of LAW or salt } \\
\text { supernates as a final mineral } \\
\text { waste form }\end{array}$ \\
\hline 3 & Sand & Sodium silicate & $\begin{array}{l}\text { Pretreatment of LAW for } \\
\text { vitrification and/or recycle of } \\
\text { melter off-gas blowdown. }\end{array}$ \\
\hline 2 & $\mathrm{Al}(\mathrm{OH})_{3}$ & Sodium aluminate & $\begin{array}{l}\text { Pretreatment of LAW for } \\
\text { vitrification and/or recycle of } \\
\text { melter off-gas blowdown. }\end{array}$ \\
\hline 3 & None & Sodium carbonate & $\begin{array}{l}\text { Pretreatment of LAW for } \\
\text { vitrification and/or recycle of } \\
\text { melter off-gas blowdown. }\end{array}$ \\
\hline
\end{tabular}

\footnotetext{
* Pyrolysis chemically decomposes organic materials by heat in the absence of oxygen

$\dagger \quad$ The solution was diluted to $5.2 \mathrm{M} \mathrm{Na}^{+}$to homogenize the feed before processing due to the observation of precipitated solids in the feed tank
} 


\section{EXPERIMENTAL}

Scoping FBSR tests were performed by TTT between December 6, 2001 and December 20, 2001 using the Studsvik THOR $^{\text {sm }}$ process. The FBSR waste forms were made Hanford AN-107 LAW simulant. The results of the final waste form testing performed by TTT under reducing FBSR conditions will be summarized in this report (Scoping Tests 1 and 2 and Production Run 2). Additional testing performed under oxidizing FBSR conditions will be discussed comparatively since there was only one set of tests run under these conditions.

Sample SCT02-098-FM was dissolved using a lithium borate fusion and a second dissolution performed via an $\mathrm{Na}_{2} \mathrm{O}_{2}$ fusion (ASTM C1463). Each dissolution was performed twice on two different days. Each dissolution was analyzed twice, once with no dilution and once with a 10X dilution. All four replicate analyses were averaged. A glass standard, Batch 1 glass, was analyzed simultaneously for quality assurance. The sample was analyzed for anions (phosphorous and sulfur) and cations by both Inductively Coupled Plasma Emission Spectroscopy (ICP-ES) and Inductively Coupled Plasma Mass Spectroscopy (ICP-MS) (ASTM C1463). In addition, the sample was dissolved in a $\mathrm{Na}_{2} \mathrm{O}_{2}$ dissolution with a water uptake and analyzed for additional anions by Ion Chromotography (IC) (ASTM D4327). The PCT leachates were analyzed for cations by both Inductively Coupled Plasma Emission Spectroscopy (ICP-ES) (ASTM C1109) and Inductively Coupled Plasma Mass Spectroscopy (ICP-MS).

Dissolution of sample SCT02-098-FM was also performed by $\mathrm{H}_{2} \mathrm{SO}_{4} / \mathrm{HF}$ in the presence of $\mathrm{NH}_{4} \mathrm{VO}_{3}$ followed by colorimetric determination of $\mathrm{Fe}^{2+}$ and total iron $\left(\sum \mathrm{Fe}\right)$ in order to determine the REDuction/OXidation (REDOX) equilibria of the sample in terms of the $\mathrm{Fe}^{2+} / \sum \mathrm{Fe}$ ratio [4]. A standard glass, the EA glass [5], with a known and reproducible REDOX, was used during the analysis for quality assurance.

X-Ray Diffraction (XRD) analyses were performed by TTT and confirmed at SRTC for sample SCT02-098-FM. XRD was performed at SRTC both before and after durability testing.

The waste form durability and chemical analyses specific to Scoping Test 02 when the FBSR was operated under reducing conditions will be discussed in detail. Coal was used to assist in denitration of the waste at temperatures between $715-735^{\circ} \mathrm{C}$. Clay, small amounts of excess $\mathrm{SiO}_{2}$, and iron oxide were the only waste form additives. The waste loading achieved with Scoping Test 02 was 27 $\mathrm{wt} \%$ since $73 \mathrm{wt} \%$ additives were used. This corresponds to a $\mathrm{Na}_{2} \mathrm{O}$ loading of $\sim 20 \mathrm{wt} \%$ in the mineral waste form.

Durability testing of the FBSR sample SCT02-098-FM from Scoping Test 02 was performed at SRTC. Durability testing was performed using ASTM C128597 (PCT-A test protocol). The PCT-A test was run for 7 days at $90^{\circ} \mathrm{C}$ in stainless steel vessels. Triplicate samples were tested along with two standard glasses; the ARM-1 standard and the Environmental Assessment (EA) glass [5] standard used to assess the durability of HLW vitrified waste forms. Testing of the FBSR final waste form using the EPA TCLP protocol was performed by Evergreen 
Analytical, an EPA certified laboratory, under subcontract to TTT. The results of the testing of samples from the FBSR process fabricated under both reducing and oxidizing conditions are summarized in this report.

\section{RESULTS AND DISCUSSION}

\section{Chemical Analysis of the FBSR Mineral Product}

A complete chemical analysis of FBSR Scoping Test 02 Sample SCT02-098FM was performed. The average of the replicate analyses is given in Table II. The replicate REDOX analyses are given in Table III. The average REDOX of the two replicate analyses in Table III were used to calculate the relative proportions of $\mathrm{FeO}$ and $\mathrm{Fe}_{2} \mathrm{O}_{3}$ in the FBSR mineral waste form as given in Table II.

The REDOX measurements in Table III indicate that the mineral phases are not overly reduced at a $\mathrm{Fe}^{+2} / \Sigma \mathrm{Fe}$ of 0.15 even in the presence of coal added for denitration of the feed. REDOX ratios of 0.15 are too oxidizing for any metallic iron to be present in the FBSR product.

The data in Table II indicate that $\mathrm{Cs}, \mathrm{Re}, \mathrm{SO}_{4}, \mathrm{Cr}$, and $\mathrm{Pb}$ are retained in the FBSR mineral phases and do not volatilize during processing. This was confirmed by the TTT analyses of the off-gas during processing

Based on the analysis provided in Table II, a waste loading of $27 \mathrm{wt} \%$ was calculated by assuming that all of the $\mathrm{SiO}_{2}$, all of the $\mathrm{Al}_{2} \mathrm{O}_{3}$ and all of the $\mathrm{Fe}_{2} \mathrm{O}_{3}$ and $\mathrm{FeO}$ are waste form additives.

Table II. Chemical Analysis of FBSR Sample SCT02-098-FM

\begin{tabular}{|c|c|c|c|c|c|c|c|}
\hline $\begin{array}{l}\text { Analytic } \\
\text { Method }\end{array}$ & Oxide & $\begin{array}{c}\text { Wto/o } \\
5 / 31 / 02\end{array}$ & $\begin{array}{c}\text { Wto } \\
8 / 15 / 02 \\
\end{array}$ & $\begin{array}{l}\text { Analytic } \\
\text { Method }\end{array}$ & Oxide & $\begin{array}{c}\text { Wto } \\
5 / 31 / 02\end{array}$ & $\begin{array}{c}\text { Wt\% } \\
8 / 15 / 02\end{array}$ \\
\hline ICP-ES & $\mathrm{Al}_{2} \mathrm{O}_{3}$ & 31.7436 & 38.924 & ICP-ES & $\mathrm{P}_{2} \mathrm{O}_{5}$ & 0.2176 & 0.2474 \\
\hline ICP-ES & $\mathrm{B}_{2} \mathrm{O}_{3}$ & & BDL & ICP-ES & $\mathrm{PbO}$ & 48 & 0.0199 \\
\hline ICP-ES & $\mathrm{CaO}$ & 0.7332 & 0.5681 & ICP-MS & $\mathrm{PbO}$ & 0.0175 & NA \\
\hline ICP-ES & $\mathrm{Cr}_{2} \mathrm{O}_{3}$ & & 0.0278 & ICP- & $\mathrm{ReO}_{2}$ & & 0.0006 \\
\hline ICP-MS & $\mathrm{Cs}_{2} \mathrm{O}$ & 0.0029 & 0.005 & ICP-ES & $\mathrm{SiO}_{2}$ & 34.8706 & 30.0572 \\
\hline ICP-ES & $\mathrm{Fe}_{2} \mathrm{O}_{3}$ & 5.44 & 6.23 & ICP-ES & $\mathrm{SO}_{4}$ & 1.1175 & NA \\
\hline ICP-ES & $\mathrm{FeO}$ & 0.87 & 1.001 & IC & $\mathrm{SO}_{4}$ & NA & 2.6335 \\
\hline ICP-ES & $\mathrm{K}_{2} \mathrm{O}$ & & 0.6794 & IC & $\mathrm{Cl}$ & NA & 0.318 \\
\hline ICP-ES & $\mathrm{La}_{2} \mathrm{O}_{3}$ & 0.0117 & NA & IC & $\mathrm{NO}_{2}$ & $<0.0005$ & NA \\
\hline ICP-ES & $\mathrm{Na}_{2} \mathrm{O}$ & 19.8156 & 16.7826 & IC & $\mathrm{NO}_{3}$ & $<0.0005$ & NA \\
\hline ICP-ES & $\mathrm{NiO}$ & 0.0814 & 0.0350 & & SUM & 95.9681 & 97.525 \\
\hline
\end{tabular}


Table III. Replicate Redox Analyses of FBSR Sample SCT02-098-FM

\begin{tabular}{cccc} 
Analysis & EA Standard & AN107-A & AN107-B \\
\hline $\mathrm{Fe}^{+2}$ & 0.088 & 0.058 & 0.056 \\
$\Sigma \mathrm{Fe}_{(\text {total })}$ & 0.458 & 0.377 & 0.376 \\
$\mathrm{Fe}^{+2} / \Sigma \mathrm{Fe}$ & 0.192 & 0.154 & 0.149
\end{tabular}

\section{X-Ray Diffraction Analysis of the FBSR Mineral Product}

The phases identified by TTT in the FBSR Sample from Scoping Test 02 (Sample SCT02-098-FM) are given in Table IV. The phases identified for the same sample at SRTC are given for comparison in Table IV. Analysis at SRTC indicated the presence of a minor second iron oxide phase, magnetite $\left(\mathrm{Fe}_{3} \mathrm{O}_{4}\right)$ in addition to the hematite $\left(\mathrm{Fe}_{2} \mathrm{O}_{3}\right)$. Nepheline (the hexagonal type) is the major component with subordinate amounts of nosean and corundum. A cubic structured nepheline was not observed in this sample but was observed in the production run of a similar material. The relative amounts of the two types of nepheline and sodalite (nosean) will vary with optimization of waste additives, e.g. types of clay or other aluminosilicates, and processing parameters.

Table IV Phases Identified in FBSR Sample SCT02-098-FM

\begin{tabular}{ccc}
$\begin{array}{c}\text { Mineral Phases Identified } \\
\text { by TTT }\end{array}$ & $\begin{array}{c}\text { Mineral Phases Identified } \\
\text { by SRTC before PCT-A } \\
\text { Testing }\end{array}$ & $\begin{array}{c}\text { Mineral Phases Identified } \\
\text { by SRTC after PCT-A } \\
\text { Testing }\end{array}$ \\
\hline $\mathrm{Na}_{8} \mathrm{Al}_{6} \mathrm{Si}_{6} \mathrm{O}_{24}\left(\mathrm{SO}_{4}\right)$ & $\mathrm{Na}_{8} \mathrm{Al}_{6} \mathrm{Si}_{6} \mathrm{O}_{24}\left(\mathrm{SO}_{4}\right)$ & $\mathrm{Na}_{8} \mathrm{Al}_{6} \mathrm{Si}_{6} \mathrm{O}_{24}\left(\mathrm{SO}_{4}\right)$ \\
$(\mathrm{Nosean})$ & $(\mathrm{Nosean})$ & $(\mathrm{Nosean})$ \\
$\mathrm{NaAlSiO}_{4}$ (Nepheline) & $\mathrm{NaAlSiO}_{4}$ (Nepheline) & $\mathrm{NaAlSiO}_{4}$ (Nepheline) \\
$\mathrm{Al}_{2} \mathrm{O}_{3}$ (Corundum) & $\mathrm{Al}_{2} \mathrm{O}_{3}$ (Corundum) & $\mathrm{Al}_{2} \mathrm{O}_{3}$ (Corundum) \\
$\mathrm{Fe}_{2} \mathrm{O}_{3}$ (Hematite) & $\mathrm{Fe}_{2} \mathrm{O}_{3}$ (Hematite) & $\mathrm{Fe}_{2} \mathrm{O}_{3}$ (Hematite) \\
& $\mathrm{Fe}_{3} \mathrm{O}_{4}$ (Magnetite) & $\mathrm{Fe}_{3} \mathrm{O}_{4}$ (Magnetite)
\end{tabular}

The sodium aluminosilicate (NAS) mineral phase assemblage(s) given in Table IV are anhydrous feldspathoid phases such as sodalite. The sodalite family of minerals (including nosean) are unique because they have cage-like structures formed of aluminosilicate tetrahedra. The remaining feldspathoid minerals, such as nepheline, have a silica "stuffed derivative" ring type structure. The cage structures are typical of sodalite and/or nosean phases where the cavities in the cage structure retain anions and/or radionuclides which are ionically bonded to the aluminosilicate tetrahdra and to sodium. The cage structured feldspathoid system of minerals has the basic structural framework formula $\mathrm{Na}_{6}\left[\mathrm{Al}_{6} \mathrm{Si}_{6} \mathrm{O}_{24}\right]$. The square brackets in the formula are used to delineate the alumina:silica ratio of the aluminosilicate cage structure which is 1:1. 
The feldspathoid mineral, sodalite has the formula $\mathrm{Na}_{8}\left[\mathrm{Al}_{6} \mathrm{Si}_{6} \mathrm{O}_{24}\right]\left(\mathrm{Cl}_{2}\right)$. The cage is occupied by two sodium and two chlorine ions in natural sodalites [6]. The formula can also be written as $\mathrm{Na}_{6}\left[\mathrm{Al}_{6} \mathrm{Si}_{6} \mathrm{O}_{24}\right] \bullet(2 \mathrm{NaCl})$ to indicate that two $\mathrm{NaCl}$ are ionically bonded in the cavities of the cage structure while the remaining $\mathrm{Na}: \mathrm{Si}: \mathrm{Al}$ have a 1:1:1 stoichiometry [6]. When the $2 \mathrm{NaCl}$ are replaced by $\mathrm{Na}_{2} \mathrm{SO}_{4}$, the mineral phase is known as nosean, $\left(\mathrm{Na}_{6}\left[\mathrm{Al}_{6} \mathrm{Si}_{6} \mathrm{O}_{24}\right]\left(\mathrm{Na}_{2} \mathrm{SO}_{4}\right)\right)$ which is one of the feldspathoid cage structured minerals found in the FBSR waste form. Since the $\mathrm{Cl}^{-}, \mathrm{SO}_{4}{ }^{\prime}$, and/or $\mathrm{S}_{2}$ are atomically bonded inside the sodalite cage structure, these species do not readily leach out of the respective FBSR waste form mineral phases.

Other minerals in the sodalite family, namely hauyne and lazurite which are also cage structured minerals, can accommodate either $\mathrm{SO}_{4}$ or $\mathrm{S}_{2}$ depending on the REDOX of the sulfur during the steam reforming process. Regardless of the FBSR REDOX the feldspathoid minerals can accommodate sulfur as either sulfate or sulfide. Sodalite minerals are known to accommodate $\mathrm{Be}$ in place of $\mathrm{Al}$ and $\mathrm{S}_{2}$ in the cage structure along with $\mathrm{Fe}, \mathrm{Mn}$, and $\mathrm{Zn}$, e.g. helvite $\left(\mathrm{Mn}_{4}\left[\mathrm{Be}_{3} \mathrm{Si}_{3} \mathrm{O}_{12}\right] \mathrm{S}\right)$, danalite $\left(\mathrm{Fe}_{4}\left[\mathrm{Be}_{3} \mathrm{Si}_{3} \mathrm{O}_{12}\right] \mathrm{S}\right)$, and genthelvite $\left(\mathrm{Zn}_{4}\left[\mathrm{Be}_{3} \mathrm{Si}_{3} \mathrm{O}_{12}\right] \mathrm{S}\right)$ [6]. These cage-structured sodalites were minor phases in High Level Waste (HLW) supercalcine waste forms ${ }^{*}$ and were found to retain $\mathrm{Cs}, \mathrm{Sr}$, and Mo into the cage-like structure, e.g. Mo as $\left(\mathrm{Na}_{6} \mathrm{Al}_{6} \mathrm{Si}_{6} \mathrm{O}_{24}\right)\left(\mathrm{NaMoO}_{4}\right)_{2}$ [7]. In addition, sodalite structures are known to retain $\mathrm{B}[8], \mathrm{Ge}[9], \mathrm{I}[9,6]$, and $\mathrm{Br}[9,6]$ in the cage like structures. Indeed, waste stabilization at Argonne National LaboratoryWest (ANL-W) currently uses a glass-bonded sodalite ceramic waste form (CWF) for disposal of electrorefiner wastes for sodium-bonded metallic spent nuclear fuel from the EBR II fast breeder reactor [10,11].

A second feldspathoid mineral found in the FBSR waste form is nepheline $\left(\mathrm{NaAlSiO}_{4}\right)$ [12]. Nepheline is a hexagonal structured feldspathoid mineral. The ring structured aluminosilicate framework of nepheline forms cavities within the framework. There are eight large (nine-fold oxygen) coordination sites and six smaller (8-fold oxygen) coordination sites [6] $]^{\cdot}$ The larger sites nine-fold sites can hold large cations such as $\mathrm{Cs}, \mathrm{K}$, and $\mathrm{Ca}$ while the smaller sites accommodate the $\mathrm{Na}$. The $\mathrm{K}$ analogue is known as leucite $\left(\mathrm{KAlSi}_{2} \mathrm{O}_{6}\right)$. In nature, the nepheline structure is known to accommodate $\mathrm{Fe}$, $\mathrm{Ti}$ and $\mathrm{Mg}$ as well.

The remaining aluminosilicate mineral found in the FBSR waste form is a sodium rich cubic structured nepheline derivative $\left(\mathrm{Na}_{2} \mathrm{O}\right)_{0.33} \mathrm{Na}\left[\mathrm{AlSiO}_{4}\right]$ (PDF\#39-0101). This nepheline derivative structure has large (twelve-fold oxygen) cage like voids in the structure [13]. This cage structured nepheline is not known to occur in nature but the large cage like voids should be capable of retaining large radionuclides, especially monovalent radionuclides such as Cs.

Supercalcines were the high temperature silicate based "natural mineral" assemblages proposed for HLW waste stabilization in the United States (1973-1985). 


\section{Durability Testing of the FBSR Mineral Product}

The PCT-A was performed in triplicate on sample SCT02-098-FM in conjunction with glass durability standards, e.g. the ARM-1 and EA glasses. Stainless steel vessels (304L) were used as specified in the PCT-A leaching protocol for the first set of tests. These tests were repeated in Teflon ${ }^{\circledR}$ vessels to demonstrate that Re release was independent of vessel type. The logarithm of the $\mathrm{NL}_{\mathrm{i}}$ was taken for each replicate and then averaged per ASTM C1285-02.

The PCT responses measured in this study for Sample SCT02-098-FM and the standard glasses tested are summarized in Table V. It is evident that the leach testing was in control as the response for the EA glass is within the allowable standard deviations of the reference response shown in Table V.

The leaching of Sample SCTO2-098-FM demonstrates that the normalized Na release is $1.74 \mathrm{~g} / \mathrm{m}^{2}$ within the $2 \mathrm{~g} / \mathrm{m}^{2}$ Hanford specification. In addition, it is obvious that the AN-107 FBSR waste form leaches incongruently instead of congruently ${ }^{*}$ as most vitrified waste forms. Incongruent dissolution of a waste form means that some of the dissolving species are released preferentially to others. Incongruent dissolution is diffusion-controlled and can be either surface reaction-limited under conditions of near saturation or mass transport-controlled. Preferential phase dissolution, ion-exchange reactions, grain-boundary dissolution, and dissolution-reaction product formation (surface crystallization and recrystallization) are among the more likely mechanism of incongruent dissolution, which will prevail, in a complex polyphase ceramic waste form [14].

Incongruent dissolution is only detrimental to a waste form if a radionculide species is released preferentially to a matrix element. In the FBSR final waste form the radionuclide release ( $\mathrm{Cs}$ and $\mathrm{Re}$ ) is retarded preferentially to the matrix element, $\mathrm{Na}$, release (Table $\mathrm{V}$ ) or conversely, $\mathrm{Na}$ is released from one of the phases preferentially compared to the nosean phase which retains the Re. This finding is noteworthy because the Hanford specification for Na release for vitrified waste forms is an indicator for the congruent release of $\mathrm{Tc}^{99}$ since $\mathrm{Na}$ and $\mathrm{B}$ and $\mathrm{Tc}^{99}$ are all released at similar stoichiometric rates (congruently) from vitrified waste forms $[10,11,15,16,17,18,19,20,21,22,23,24]$.

The incongruent release of Cs and Re is not attributed to the use of stainless steel vessels as numerous studies have shown that neither Cs nor $\mathrm{Tc}^{99}$ have an affinity for stainless steel vessels $[19,15]$. In addition, the PCT triplicate analyses were rerun in Teflon ${ }^{\circledR}$ vessels and the Re release indicated in Table V is comparable to the Re release measured in this study in the stainless steel vessels. The solids remaining after PCT testing were analyzed by X-ray Diffraction and all of the same phases were present as before PCT testing (see Table IV).

* Congruent dissolution of a waste form is the dissolving of species in their stoichiomentric amounts. For congruent dissolution, the rate of release of a radionculide from the waste form is proportional to both the dissolution rate of the waste form and the relative abundance of the radionculide in the waste form. Thus for borosilicate glass $\mathrm{Tc}^{99}$ is released at the same rate, congruently, as $\mathrm{Na}^{+}, \mathrm{Li}^{+}$and $\mathrm{B}$. 
Table V PCT Performance of Sample SCT02-098-FM and the Glass Standards Tested Compared to the Durability Response of Known Standards

\begin{tabular}{ccccccc} 
Sample & $\mathrm{pH}$ & $\begin{array}{c}\mathrm{NL}_{(\mathrm{B})} \\
\mathrm{g} / \mathrm{m}^{2}\end{array}$ & $\begin{array}{c}\mathrm{NL}_{(\mathrm{Na})} \\
\mathrm{g} / \mathrm{m}^{2}\end{array}$ & $\begin{array}{c}\mathrm{NL}_{(\mathrm{Cs})} \\
\mathrm{g} / \mathrm{m}^{2}\end{array}$ & $\begin{array}{c}\mathrm{NL}_{(\mathrm{Re})} \\
\mathrm{g} / \mathrm{m}^{2}\end{array}$ & $\begin{array}{c}\mathrm{NL}_{(\mathrm{Si}} \\
\mathrm{g} / \mathrm{m}^{2}\end{array}$ \\
\hline EA & 11.64 & 7.76 & 6.05 & & & 2.21 \\
ARM-1 & 10.47 & 0.29 & 0.27 & & & 0.15 \\
AN-107 & 11.95 & 1.27 & 1.74 & 0.16 & 0.29 & 0.35 \\
& & & & & $(0.22)^{*}$ & \\
AN-107* & 11.98 & $\mathrm{BDL}$ & $f$ & $f$ & 0.22 & 0.48 \\
EA REF & 11.85 & 8.37 & 6.67 & & & 1.96 \\
LAW REF & 10.90 & 0.55 & 0.54 & & & 0.16 \\
AN-102 RAD & 10.60 & 0.29 & 0.35 & & & 0.12 \\
& & & & & &
\end{tabular}

$*=$ rerun in Teflon vessels, $f=$ analysis indicated that vessel blanks were contaminated with $\mathrm{Na}$ and $\mathrm{Cs}$

\section{Regulatory Testing of the FBSR Mineral Waste Form}

The mineral phases formed during the FBSR process were subject to the EPA TCLP leaching protocol. All of the mineral phases, regardless of particle size, appear to have met the LDR Universal Treatment Standards (UTS) as shown in Table VI.

Delisting the final LAW waste form may also be accomplished by delisting the final waste form at the point of generation so that the UTS are not applicable. The EPA calculates delisting levels and risk levels for a given waste form using their DRAS code (EPACMTP model) for calculation of major pathways for human exposure to a given waste. If the allowable concentrations in the TCLP leachate of the waste, as calculated by DRAS, are higher than the Toxcitiy Characteristic (TC) level for the TC constituents, then the delisting level for the TC constituents can be capped at the TC regulatory limits. The UTS levels may or may not apply to a delisted waste. This is still highly debated even within the EPA. However, a waste form that meets the EPA UTS treatment standard limits should be easily delisted.

The results of the TCLP testing is provided in Table VI for FBSR products produced under reducing (Scoping Test 01 and Production Test 02) and oxidizing FBSR conditions (Production Test 01) since no TCLP testing had been performed on sample SCT02-098-FM from Scoping Test 02. 
Table VI. TCLP Testing of FBSR Final Mineral Waste Form Products

\begin{tabular}{cccc}
$\begin{array}{c}\text { Element of } \\
\text { Concern }^{\dagger}\end{array}$ & $\begin{array}{c}\text { TCLP Releases } \\
\text { for FBSR } \\
\text { Under } \\
\text { Reducing } \\
\text { Conditions } \\
\text { (ppm) }\end{array}$ & $\begin{array}{c}\text { TCLP Releases } \\
\text { for FBSR } \\
\text { Under } \\
\text { Reducing } \\
\text { Conditions } \\
\text { (ppm) }\end{array}$ & $\begin{array}{c}\text { UTS Limits } \\
\text { Federal } \\
\text { Register, V.63, } \\
\text { No. 100 } \\
\mathbf{p . 2 8 7 4 8 - 9} \\
\text { May 28, 1998 } \\
(\mathbf{p p m})\end{array}$ \\
\hline $\mathbf{C r}$ & $0.015-0.060$ & $0.001-0.018$ & 0.60 \\
$\mathbf{P b}$ & $0.005-0.023$ & $0.002-0.067$ & 0.75 \\
$\mathbf{N i}$ & $0.001-3.11$ & $0.66-2.80$ & 11 \\
\hline
\end{tabular}

* 1.0 or still hazardous

$\dagger$ As, Ba, Cd, Hg, Se, Ag, Zn, Sb, Be, Tl and V not in simulant

\section{CONCLUSIONS}

The following can be concluded about the use of Fluidized Bed Steam Reforming (FBSR) as a final waste form for Hanford's LAW waste:

- FBSR is a robust technology capable of accommodating wide ranges of feeds and additives including high concentrations of sulfate

- FBSR's ability to retain sulfate can lead to increased waste loadings and accelerated stabilization of Hanford's LAW vs. LAW vitrification

- FBSR's mineral waste species exhibit a superior durability to LAW glass in both ASTM C1285 and EPA TCLP testing

- FBSR's durability is incongruent and the radionuclides (Cs and Re as simulants for $\mathrm{Cs}^{137}$ and $\mathrm{Tc}^{99}$ ) are released at a rate lower than that of $\mathrm{Na}$ (Na release is $<2 \mathrm{~g} / \mathrm{m}^{2}$ )

- FBSR is a medium temperature process: temperatures are low enough not to vaporize radionuclides but high enough to destroy volatile organic compounds (VOC's) in the presence of a reductant and a catalyst

- FBSR waste form mineral phases are cage like structures that trap radionuclides and anions

- FBSR waste form mineral phases alter to zeolites that have the same cagelike structures and will likely still retain the radionuclides and anions

- FBSR waste forms are regulatory compliant at the Universal Treatment Standard (UTS) making delisting of the final waste form more assured (at an estimated cost savings of $\$ 5952 / \mathrm{ft}^{3}$ for disposal since disposal of listed mixed waste is $\$ 6000 / \mathrm{ft}^{3}$ while disposal as radioactive (low level) waste once the waste is delisted costs only $\$ 42 / \mathrm{ft}^{3}$ ) [25]

\section{ACKNOWLEDGEMENTS}

This paper was prepared in connection with work done under Contract No. DE-AC09-96SR18500 with the U.S. Department of Energy. 


\section{REFERENCES}

1 J.B. Mason, J. McKibben, J. Ryan, J. Schmoker, “ Steam Reforming Technology for Denitration and Immobilization of DOE Tank Wastes," Waste Mgt. 03 (February 2003).

2 C.M. Jantzen, "Engineering Study of the Hanford Low Activity Waste (LAW) Steam Reforming Process," U.S. DOE Report WSRC-TR-2002-00317, Westinghouse Savannah River Co., Aiken, SC (July 12, 2002).

3 B.P. McGrail, H.T. Schaef, P.F. Martin, D.H. Bacon, E.A. Rodriguez, D.E. McCready, A.N. Primak, and R.D. Orr, "Initial Evaluation of Steam-Reformed Low Activity Waste for Direct Land Disposal," U.S. DOE Report PNWD-3288, Battelle Pacific Northwest Division, Richland, WA (January 2003).

4 E.W. Baumann, "Colorimetric Determination of Iron (II) and Iron (III) in Glass," Analyst, v. 117, 913-916 (1992).

5 C.M. Jantzen, N.E. Bibler, D.C. Beam, and M.A. Pickett, "Characterization of the Defense Waste Processing Facility (DWPF) Environmental Assessment (EA) Glass Standard Reference Material,” U.S. DOE Report WSRC-TR-92-346, Rev.1 (February, 1993).

6 W. A. Deer, R. A. Howie, and J. Zussman, "Rock-Forming Minerals, Vol IV," John Wiley \& Sons, Inc., New York, 435pp. (1963).

7 D.G. Brookins, “Geochemical Aspects of Radioactive Waste Disposal," Springer-Verlag, New York, 347pp. (1984).

8 J.Ch. Buhl, G. Englehardt, and J. Felsche, "Synthesis, X-ray Diffraction, and MAS n.m.r. Characteristics of Tetrahydroxoborate Sodalite," Zeolites, 9, 40-44 (1989).

9 M.E. Fleet, "Structures of Sodium Alumino-Germanate Sodalites," Acta Cryst., C45, 843847 (1989).

10 W. Sinkler, T.P. O'Holleran, S.M. Frank, M.K. Richmann, and S.G. Johnson, "Characterization of a Glass-Bonded Ceramic Waste Form Loaded with $\mathrm{U}$ and Pu," Sci.Basis Nucl. Waste Mgt., XXIII, R.W. Smith and D.W. Shoesmith (Eds) Mat. Res. Soc., Pittsburgh, PA, 423-429 (2000).

11 T.L. Moschetti, W. Sinkler, T. DiSanto, M.H. Novy, A.R. Warren, D. Cummings, S.G. Johnson, K.M. Goff, K.J. Bateman, and S.M. Frank, "Characterization of a Ceramic Waste Form Encapsulating Radioactive Electrorefiner Salt,” Sci.Basis Nucl. Waste Mgt., XXIII, R.W. Smith and D.W. Shoesmith (Eds.), Mat. Res. Soc., Pittsburgh, PA, 577-582 (2000).

12 L.G. Berry and B. Mason, "Mineralogy Concepts, Descriptions, Determinations," W.H. Freeman \& Co., San Francisco, CA, 630pp (1959).

13 R. Klingenberg and J. Felsche, "Interstitial Cristobalite-type Compounds $\left.\left(\mathrm{Na}_{2} \mathbf{O}\right)_{0.33} \mathbf{N a}\left[\mathrm{AISiO}_{4}\right]\right)$," J. Solid State Chemistry, 61, 40-46 (1986).

14 C.M. Jantzen, D.R. Clarke, P.E.D. Morgan and A.B. Harker, "Leaching of Polyphase Nuclear Waste Ceramics: Microstructural and Phase Characterization," J. Am. Ceram. Soc. 65[6], 292-300 (1982).

15 N.E. Bibler, and J.K. Bates, "Product Consistency Leach Tests of Savannah River Site Radioactive Waste Glasses," Sci.Basis Nucl. Waste Mgt, XIII, Oversby, V. M. and Brown, P. W., eds., Mat. Res. Soc., Pittsburgh, PA, 1990, pp. 327-338.

16 J.K. Bates, D.J. Lam, M.J. Steindler, "Extended Leach Studies of Actinide-Doped SRL 131 Glass,” Sci. Basis Nucl. Waste Mgt, VI, D.G. Brookins (Ed.), North-Holland, New York, 183-190 (1983).

17 L.R. Morss, M.L. Stanley, C.D. Tatko, W.L. Ebert, "Corrosion of Glass Bonded Sodalite as a Function of pH and Temperature," Sci.Basis Nucl. Waste Mgt., XXIII, R.W. Smith and D.W. Shoesmith (Eds.), Mat. Res. Soc., Pittsburgh, PA, $733-738$ (2000).

18 B.P. McGrail, “ Waste Package Component Interactions with Savannah River Defenxe Waste Glass in a Low-Magnesium Salt Brine," Nuclear Technology, 168-186 (1986). 
19 W.L. Ebert, S.F. Wolf, and J.K. Bates, "The Release of Technetium from Defense Waste Processing Facility Glasses," Sci.Basis Nucl. Waste Mgt., XIX, W.M. Murphy and D.A. Knecht (Ed.), Mat. Res. Soc., Pittsburgh, PA, 221-227 (1996).

20 E.Y. Vernaz and N. Godon, "Leaching of Actinides from Nuclear Waste Glass: French Experience," Sci.Basis Nucl. Waste Mgt., XV, C.G. Sombret (Ed) Mat. Res. Soc., Pittsburgh, PA, 37-48 (1992).

21 N.E. Bibler and A.R. Jurgensen, "Leaching Tc-99 from SRP Glass in Simulated Tuff and Salt Groundwaters," Sci.Basis Nucl. Waste Mgt, XI, M.J. Apted and R.E. Westerman (Eds.), Mat. Res. Soc., Pittsburgh, PA, 585-593 (1988).

22 D.J. Bradley, C.O. Harvey, and R.P. Turcotte, "Leaching of Actinides and Technetium from Simulated High-Level Waste Glass," Pacific Northwest Laboratory Report, PNL3152, Richland, WA (1979).

23 S. Fillet, J. Nogues, E. Vernaz, and N. Jacquet-Francillon, "Leaching of Actinides from the French LWR Reference Glass," Sci.Basis Nucl. Waste Mgt, IX, L.O. Werme, Mat. Res. Soc., Pittsburgh, PA, 211-218 (1985).

24 F. Bazan, J. Rego, and R.D. Aines, "Leaching of Actinide-doped Nuclear Waste Glass in a Tuff-Dominated System," Sci.Basis Nucl. Waste Mgt, X, J.K. Bates and W.B. Seefeldt (Eds.), Mat. Res. Soc., Pittsburgh, PA, 447-458 (1987).

25 Savannah River Site Training Radiological Worker Training Study Guide, Rev. 11, Westinghouse Savannah River Company (1997). 